\title{
SCHOOLING AND PARENTAL DEATH
}

\author{
Paul Gertler, David I. Levine, and Minnie Ames*
}

Abstract-Loss of a parent is one of the most traumatic events a child can face. If loss of a parent reduces investments in children, it can also have long-lasting implications. This study uses parametric and seminonparametric matching techniques to estimate how one human capital investment, school enrollment, is affected by a parent's recent death. We analyze data from 600,000 households from Indonesia's National Socioeconomic Survey (Susenas) during 1994-1996. We find a parent's recent death has a large effect on a child's enrollment. We also use this shock to test several theories of intrahousehold allocation and find little differential treatment based on the gender of the child or the deceased parent.

\section{Introduction}

L OSS of a parent while one is still young is likely to be the most traumatic event in a child's life. If loss of a parent reduces investments in children's human capital, it can also have long-lasting implications for their quality of life and livelihood. A significant proportion of school-aged children in less industrialized nations have always lost parents to accidents, childbirth, and illness. Unfortunately, the scourge of HIV/AIDS has greatly increased death rates of young adults in much of the world and thus increased the importance of understanding how parental loss affects investments in children. For example, one in ten African children under the age of 15 has lost one or both parents (Hunter \& Williamson, 2000). In this paper we study how loss of a parent affects children's school enrollment in Indonesia.

The international community has become increasingly concerned about the effect of adult mortality on children's schooling (Copson, 2002; World Bank, 1999). Many programs, especially in Africa, have been launched or proposed to support the school fees, uniforms, and other schoolingrelated costs of orphaned children (Hunter \& Williamson, 2000; Reid, 1993). However, the empirical evidence to support these policies is weak. Lloyd and Blanc (1996) use population surveys with limited socioeconomic controls from seven African countries and find mixed results. Ainsworth, Beegle, and Koda (2000) analyze a well-designed panel survey of 757 households from Northwestern Tanzania and find that adult mortality delays school entry, but otherwise does not affect enrollment. Indeed, there are conditions under which theoretical models predict no effect of parental death on enrollment (Becker \& Tomes, 1979).

One of the difficulties in studying the effects of parental mortality on children's schooling is finding data sets large enough to capture sufficient cases of prime-age adult mortality linked to the socioeconomic status of the household.

Received for publication October 22, 2001. Revision accepted for publication March 14, 2003.

* UC Berkeley and NBER; UC Berkeley; and Harvard Medical School, respectively.

We have benefited from comments by Mark Gilkey and Daniel Levine, and able research assistance from Sebastian Martinez. Gertler and Ames gratefully acknowledge financial support from NICHD.
We analyze data from Indonesia's National Socioeconomic Survey, known by its Indonesian acronym Susenas. The Susenas is an annually repeated cross section of approximately 200,000 households. We examine three years of Susenas surveys, from 1994 to 1996, and therefore have a sample of over 600,000 households. Susenas collects information on the general welfare of each household member, including school enrollment and mortality in the twelve months prior to the survey. Our bereaved sample $(3,119$ observations) includes individuals age 6 through 20, who live in households where either the mother or the father died within the year prior to the survey.

Like other research on the effects of family composition and income changes, this study carefully treats the problem of endogeneity; specifically, families that lose a parent were often disadvantaged before the loss of the parent. In addition to a standard parametric technique (conditional logit with a fixed effect for each community), our large sample allows us to address the problems of nonrandom selection with a seminonparametric technique that matches youth who lose a parent to similar control youth who have similar observable characteristics and live in the same neighborhood.

We find a parent's recent death has a large effect on a child's enrollment. A child whose parent has recently died is on average 2.0 times more likely to drop out than children with living parents. This effect is highest for youth at the transitions between primary and junior secondary and between junior secondary and senior secondary. We also use this shock to test several theories of intrahousehold allocation and find little differential treatment with respect to the gender of the child or of the deceased parent.

\section{Theoretical Framework}

The theoretical literature on intergenerational altruism, mutual insurance, and intrahousehold allocation describes a number of pathways by which the loss of a parent might reduce the family's subsequent investments in a surviving child's human capital. For example, loss of a parent decreases financial resources and parental involvement- two key inputs into education. In addition, household preferences for the quality of children may change. There may also be psychological costs associated with a recent death. Finally, the value of a child's time when at home may change.

In the empirical work, however, we will not be able to identify the specific pathways. Rather, the focus of the empirical work is to estimate the cumulative effect on children's schooling via all pathways. For this reason, we do not put forward a formal theoretical model, but rather summarize the main theoretical arguments in the literature by which the loss of a parent might reduce investments in children. 
We organize the discussion by first presenting a strawman model in which the death of a parent does not affect a family's investment in their children. This model, first presented by Becker and Tomes (1979), has a number of strong assumptions. We then relax each of these assumptions to help us understand when the loss of a parent might reduce enrollments. We then discuss the conditions under which daughters might be affected less than sons and when the loss of a mother might matter more than the loss of a father. We end the section with a review of the existing empirical literature that indirectly supports the theory.

\section{A. The Straw Man}

In a seminal paper, Becker and Tomes (1979) developed a model of investments in children's human capital motivated by intergenerational altruism. In their model, they assume that (1) there are perfect capital markets, so that parents are not liquidity-constrained and can borrow against their children's future earnings, (2) schooling is valued solely for its contributions to future income, (3) neither investment of parental time nor the process of bereavement affects the value of schooling, (4) the opportunity cost of children's time is not affected by the death of a parent, and (5) parents care equally about each child and make decisions to pay for education solely based on education's effects on future productivity (that is, not based on ascribed characteristics such as sex).

They derive the familiar result that a family's optimal investment is that which equates the marginal returns to education to the marginal costs. Under the strong assumptions noted above, when parents can freely borrow against the future earnings of their children, investments in children are unaffected by shocks to a family's current income such as loss of a parent. Intuitively, parents undertake investments with positive present values, and current income does not affect the payoff from the investment.

\section{B. Liquidity Constraints and Insurance}

In a follow-up paper, Becker and Tomes (1986) revisit the question of parental investments in children in the presence of imperfect capital markets such that families cannot borrow against future higher earnings that educated children will receive. In this case, investments in children remain unaffected after a negative income shock for families with sufficient assets (that is, precautionary savings), but investment declines for families with liquidity constraints.

However, liquidity constraints may not be a problem if families are able to insure against unexpected parental death. In many industrialized nations, parents purchase life insurance to help smooth the living standard of and investments in their children if a parent dies. Although this mechanism is not widely used in Indonesia, informal insurance from neighbors and the extended family can be important factors in maintaining investments in children (Townsend, 1995).
The ethnographic literature on Indonesia suggests that informal insurance within neighborhoods was often quite important after a family received a negative shock (see, for example, Sullivan, 1994). For example, the traditional Javanese funeral involves monetary gifts to the family of the deceased. Moreover, meals, child care, and other resources are often provided by long-time neighbors to help maintain children's well-being. Well-working informal insurance markets also provide a rationale for stable enrollment after loss of a parent in the presence of imperfect capital markets.

At the same time, both in formal models of insurance and in the ethnographies of Indonesia, less positive outcomes are possible. Mutual insurance is easiest to maintain when there is the potential for reciprocity, that is, if you are able to help out the person who helped you in your bad times when they have bad times. A permanent shock such as the death of a prime-age parent makes such reciprocity less likely to occur. Thus, when insurance is maintained by expected future reciprocity, it will not work well for large shocks (Townsend, 1994; Sullivan, 1994), which suggests that enrollment might decline.

\section{Preferences and Production}

Relaxing the other strong assumptions about preference and the education production function provides three additional pathways by which parental death can adversely affect children even when a family has no borrowing constraints or when they have access to well-working insurance mechanisms.

First, when education is partly a parental consumption good (not just investment), enrollments may decline after a family's income declines.

Second, if parental time is an argument of the education production function, there is likely to be less investment in schooling. When a parent dies there is less total time available to spend working and in household production activities, including helping children with homework or transporting them to school. If schooling is more productive when parental involvement is high and if the surviving parent spends less time helping children with their schooling than two parents would have, the marginal benefits of a child's education falls. Thus, if parental time is an input into education, loss of a parent might reduce enrollments even when parents can borrow against children's future earnings.

Conversely, if parental time is a substitute for schooling, schooling may rise after the loss of a parent. For example, schools may provide child care for children who would otherwise need adult supervision if they remained at home. This effect is mostly likely to hold for children who need the most parental supervision, such as those in the early primary grades.

Finally, loss of a parent is tremendously traumatic, and it may affect the bereaved child's emotional status and values. The trauma of bereavement may make it difficult for children to study, and children may temporarily or permanently 
withdraw from school. Similarly, a parent who dies when a child is young may not have been able to pass on norms and values. Indeed, many children remain in school because of their family values. When a parent disappears from the household, children may no longer have the motivation to continue their education.

\section{Sons versus Daughters}

The discussion so far has focused on the conditions under which the death of a parent would reduce the amount invested in children's education. However, the effect may not be uniform within the household. Indeed, Alderman and Gertler (1997) posit several conditions under which daughters tend to bear a disproportionate share of bad shocks. ${ }^{1}$ The effect of parental death will be smaller on sons than on daughters if sons traditionally care for parents in old age or if sons have a higher return to education. Moreover, parents may have preferences for higher education for their sons; often these preferences are related to widely held norms of gender roles. For example, a survey of village experts in traditional law in Indonesia found that roughly half of villages had traditions of giving sons preference in education over daughters. As the male-female gap in Indonesia has declined in recent decades, so has this tradition; only one-seventh of village heads suggested that 1997 practices were still unequal (Kevane \& Levine, 2002). Under plausible conditions, when parents prefer sons on average, parents will invest marginal resources in daughters; correspondingly, daughters will lose more when living standards decline.

When parents find their time stretched, the value of children's time outside of school may increase. Most importantly, the ethnographic literature on Indonesia stresses the important role that oldest daughters often play in caring for younger siblings. When a parent dies, the remaining parent is particularly likely to find this assistance useful. In the framework of Becker and Tomes's theory, a higher opportunity cost of time reduces enrollments.

If parents try to protect sons, then children (both male and female) with many brothers will be at particularly high risk (Garg \& Morduch, 1998). Intuitively, in cultures where sons are very important, an only son is privileged, whereas a sister with many brothers, or a brother with many brothers, is less likely to receive extra protection. If this betweensibling competition is important, then enrollment rates among families that lose a parent may decline more if the proportion of brothers is large (controlling for family size).

\footnotetext{
${ }^{1}$ The hypothesis of daughters being more at risk has been confirmed in a number of studies. For example, investments in sons are more likely to be protected during famines (Drèze \& Sen, 1989) and after bad harvests (Rose, 1999; Cameron \& Worsick, 2001) than are investments in daughters.
}

\section{E. Loss of Father versus Mother}

The loss of a father may have a greater impact than the loss of a mother if men have higher earning power. In Indonesia, men in the wage-earning sector earn substantially more than do women of similar observable qualifications. ${ }^{2}$ Moreover, men are more likely to work in the relatively well-paid formal sector than are women. ${ }^{3}$ If liquidity constraints are the main constraints on children's education, these labor market inequalities imply that loss of a father should affect education more than loss of a mother.

On the other hand, there are reasons to believe that the loss of a mother may be more important than the loss of a father. Moreover, a number of models of intrahousehold bargaining imply that household decisions such as investments in children are complex averages of both parents' (and perhaps the children's) preferences. In these models, a household member's preferences affect resource allocation in proportion to her contribution to household resources. ${ }^{4}$ There is evidence from other developing countries that mothers tend to invest more of the income they control in children than do fathers (Haddad \& Hoddinott, 1994; Thomas, 1997). Thus, the loss of the mother may adversely affect investment in children not only through an income effect, but also through a substitution effect away from investments in children due to increasing importance of the preferences of the father. Similarly, if mothers favor daughters more than fathers do, then the loss of a mother will affect daughters even more than the loss of a father.

There are two other Indonesia-specific reasons why the loss of mother might be more important. First, Indonesian mothers do the bulk of child-rearing work. These tasks may be important complements to education; for example, consider the time it takes to help a child get dressed, fed, and transported to school. Also, in many parts of Indonesia, social support networks are based on the mother, not the father (Geertz, 1963; Manderson, 1983).

These inequalities in traditional time-use patterns, preferences, and social support imply that, holding all else constant, loss of a mother should affect education more than loss of a father. The relative importance of maternal loss should be highest for elementary school children, when the time it takes to help a child attend school is greatest. These predictions are supported by Ainsworth et al. (2000), who measured the impact of adult mortality on enrollment in Northwestern Tanzania.

\footnotetext{
${ }^{2}$ Source: 1996 National Labor Force Survey (Sakernas). A median regression shows women earn 39\% lower wages than men of similar age and education. [To be precise, the estimate was 0.39 lower $\log$ (wages) for women.]

${ }^{3}$ Source: Susenas.

${ }^{4}$ For an introduction to the many theories of intrahousehold allocation, see the models in Haddad, Hoddinott, and Alderman (1997).
} 


\section{F. Evidence}

There is some indirect empirical evidence to support the prediction that children's outcomes, including educational achievement, are adversely affected by a parent's death. A number of studies report positive correlation of child outcomes with family resources, such as income, education, assets, and time. Research in the United States has found that parental income has an important positive effect on educational attainment [Hill and Duncan (1987) and Haveman and Wolfe (1995) review this literature; contra see Mayer (1997)], and that achievement in school is positively linked to parental investments of time (Datcher-Loury, 1988; Steelman \& Mercy, 1980; Leibowitz, 1974).

The effect of parental absence on children's educational outcomes through divorce (a less severe shock than death of a parent) has also been well documented. A number of studies provide evidence that children in single-parent families have lower grades, poorer school attendance, higher dropout rates, and more problems with school authorities (Astone \& McLanahan, 1991; Downey, 1994; Hetherington, Camara, \& Featherman, 1983; Krein \& Beller, 1988; McLanahan, 1985; Pong, 1997). However, school achievement and family structure may be jointly determined by unobservable family characteristics (Levine \& Painter, 2000).

\section{The Context}

With a population just over 200 million, Indonesia is the fourth most populous nation in the world. From 1980 until the economic crisis of 1997, Indonesia experienced very rapid economic growth of over $6 \%$ per year. Despite the country's rapid increase in wealth, the average Indonesian remained quite poor. Even before the 1997 financial crisis, almost $10 \%$ of Indonesians lived beneath the poverty line of approximately $\$ 1$ per day.

Indonesia has made substantial improvements in education over the last 20 years. Due partly to school expansion efforts and a compulsory education law passed in 1984, primary enrollment increased from $79 \%$ to $95 \%$ from 1983 to $1999.5^{5}$ While the average 50 -year old in Indonesia in 1999 had 5.1 years of schooling, the average 20-year-old had 8.7 years. Nevertheless, compared to other nations in the region and to other nations with similar income per capita, Indonesia had higher infant mortality, lower life expectancy, and more child malnutrition even before the financial crisis.

Unlike many Asian nations, educational achievement of boys and girls is close to parity through secondary school. In 1999, girls had slightly higher primary school enrollment than boys (95.6\% versus $94.9 \%$, ages $7-12$ ), whereas boys had slightly higher early secondary school enrollment (79.3\% versus $78.7 \%$, ages $13-15)$. This enrollment gap

\footnotetext{
${ }^{5}$ Government of Indonesia, 1996. The 1999 figure is from Susenas, as described below.
}

widens only a small amount in late secondary school, with boys at $51.5 \%$ and girls at $50.8 \%$ (ages 16-18).

Despite the facts that education in Indonesia is inexpensive and widely accessible, many families choose not to keep their children in school. Common motives for not enrolling children include (especially for poor families) the cost of uniforms and supplies, difficulties commuting in some areas, and the usefulness of child and youth labor at home, on the family farm, or in employment. This paper examines the effect of a large financial shock, the death of a parent, on children's subsequent enrollment.

Indonesia is an important place to examine the effects of adult mortality on children because, as in many developing countries, access to formal insurance mechanisms is poor. Only $1.8 \%$ of households in 1999 paid for any kind of insurance. Furthermore, almost half of Indonesian workers were self-employed in 1999, and few companies offer death benefits. With weak formal insurance systems and low initial income and assets in most families, many Indonesian children are at risk of harm after a decline in family resources.

In spite of the weak formal institutions, several informal institutions may reduce harm to children after the loss of a parent. ${ }^{6}$ Most directly useful in the short run is the tradition (at least on Java, where roughly half of Indonesians live) that neighbors and family members who attend a funeral contribute cash and food to the survivors. In the longer term, the Muslim tradition of giving alms to widows and their children at least once a year can be helpful in communities where that tradition functions well. Also important in the longer term is the common custom of fostering out children to relatives in hard times.

\section{Data Sources and Analysis Sample}

We analyze data from Susenas surveys, from 1994 to 1996, and have a sample of over 600,000 households. Susenas surveys the head of the household on the general welfare of each household member in matters such as school enrollment, health, and mortality. For household members over age 4 , Susenas has information on current school attendance, the highest school level ever attended, and the highest grade ever attended. School levels range from primary school to senior high school and above.

The Susenas sample was selected to be representative for each of Indonesia's roughly 300 districts. The 36,000 enumeration areas surveyed are drawn from the nation's 176,582 enumeration areas (Surbakti, 1997, p. 23). The Indonesian Bureau of Statistics mapped enumeration areas so that they have clear boundaries and between 200 and 300 households each (Surbakti, 1997, p. 29). Although Indonesian cities are often more complexly laid out than are

${ }^{6}$ See Sullivan (1994), Geertz (1961, pp. 26, 29, 83), and Jellinek (1991) for ethnographic descriptions of these institutions. 
Table 1.-Educational Conditioning of Bereaved and Control Groups

\begin{tabular}{|c|c|c|c|c|c|}
\hline \multirow{2}{*}{$\begin{array}{l}\text { Normative } \\
\text { Grade }\end{array}$} & \multirow{2}{*}{$\begin{array}{l}\text { Age } \\
\text { Group }\end{array}$} & \multirow[b]{2}{*}{ Conditioned on: } & \multicolumn{3}{|c|}{ Sample Observations } \\
\hline & & & Bereaved & Control & Total \\
\hline 1 & $6-9$ & Started first grade & 745 & 3,495 & 4,240 \\
\hline 2 & $7-10$ & Started second grade & 788 & 3,568 & 4,356 \\
\hline 3 & $8-11$ & Started third grade & 750 & 3,059 & 3,809 \\
\hline 4 & $9-12$ & Started fourth grade & 809 & 3,225 & 4,034 \\
\hline 5 & $10-13$ & Started fifth grade & 771 & 2,927 & 3,698 \\
\hline 6 & $11-14$ & Started sixth grade & 783 & 2,686 & 3,469 \\
\hline 7 & $12-15$ & Started seventh grade & 548 & 1,820 & 2,368 \\
\hline 8 & $13-16$ & Started eighth grade & 513 & 1,617 & 2,130 \\
\hline 9 & $14-17$ & Started ninth grade & 437 & 1,307 & 1,744 \\
\hline 10 & $15-18$ & Started tenth grade & 307 & 760 & 1,067 \\
\hline 11 & $16-19$ & Started eleventh grade & 292 & 699 & 991 \\
\hline 12 & $17-20$ & Started twelfth grade & 225 & 524 & 749 \\
\hline
\end{tabular}

Notes: Bereaved households lost a parent in the previous year. Controls are two-parent households in the same neighborhood, with a child of the same age and schooling level as a bereaved household. The total number of distinct observations ( 3,119 bereaved children and 14,315 controls) is less than the sum of the columns above because some observations are listed in more than one age group.

American cities, one can think of enumeration areas as similar to a U.S. city block.

Our bereaved sample $(3,119$ observations) includes respondents aged 6 through 20 who are children of the household head and spouse, and who live in households where either the head or spouse died within the year prior to the survey. ${ }^{7}$ Our control group (14,315 observations) consists of respondents aged 6 through 20 who live in a household where their parent is the household head and that is in the same neighborhood as a child who lost a parent. By comparing households in roughly the same block, our geographic controls capture many dimensions of the household, such as exposure to contagious diseases or distance to a health clinic or school. Moreover, in Indonesia, as in the rest of the world, geographic segregation based on income, education, ethnicity, and other factors has important effects on investments in children.

The Susenas data set provides cross-sectional data on enrollments, yet we would like to be able to examine how changes in the number of surviving parents affect changes in enrollment. To calculate the change in enrollment, we have selected a population that is near the age-appropriate grade level. This population is likely to have been enrolled in the previous year. For example, if a 15-year-old's educational attainment is the fourth grade, we do not consider her for the sample at risk of dropping out of high school last year. Specifically, we have divided bereaved and control observations into overlapping 4-year age groups, conditioned on the attainment of an age-adjusted education level, as table 1 details. The age-appropriate school level for each 4-year age group was determined by a nationwide analysis

\footnotetext{
${ }^{7}$ Susenas links children with their biological mother if she lives in the same household, which allows us to exclude stepmother cases from the controls. Susenas also gives each member's relationship to the household head, who is usually male, but does not distinguish between children and stepchildren. We are therefore unable to exclude many stepfather cases. Furthermore, because information linking children to their father is only available for children and stepchildren of the household head, other children are excluded from this study.
}

that shows approximately 95\% of students currently enrolled in each grade level are in the designated 4-year age group (see appendix A).

By selecting control children that are the same age, have the same education level, and are in the same neighborhood as bereaved children, we obtain two groups that are similar with respect to many household characteristics. As table 2 shows, bereaved and control households have similarquality housing.

Because bereaved households generally have older household heads and spouses, however, family composition varies slightly between bereaved and control households. On average, bereaved families have 0.38 fewer children than control families (gap significant at the 5\% level). Furthermore, household head and spouse education levels vary between the two household types. This gap is, again, because bereaved heads and spouses are older than controls, and older Indonesians generally have had less education.

Not surprisingly, consumption patterns vary between the household that did and did not suffer the loss of a parent the previous year. Bereaved and control households are not significantly different in the share, or per capita rupiah value, spent monthly on food and nonfood consumption (table 3). They do vary, however, in the distribution of nonfood spending. Bereaved households spend an average of $11.8 \%$ more of their total monthly expenditures on health and ceremony expenses than control households do. These higher expenditures are expected in families that lost an adult and hosted a funeral. Both the bereaved and control households we have selected had total expenditures on average $4.6 \%$ less per month per capita than the average Indonesian household.

\section{Methods}

Our first set of analyses compares enrollment means of students in the bereaved and control samples, divided into 12 overlapping age groups. The gap in enrollment between these two groups is due both to parental death and to any household characteristics that differ between families that live in the same neighborhood but are at high or low risk of parental death. We use both parametric and nonparametric methods to control for any differences.

\section{A. Regression Adjustments}

We control for variables that jointly determine enrollment and parental death by estimating a logistic regression for the probability of enrollment, controlling for observable household characteristics, with a fixed effect for each enumeration area. This parametric approach allows us to control for community characteristics that are common to all households in the enumeration area as well as observed household characteristics that may be correlated with death and enrollment, such as parent's age, household size, household 
Table 2.-Descriptive Statistics of Bereaved, Control, and All Households

\begin{tabular}{|c|c|c|c|c|c|c|c|c|}
\hline & \multicolumn{2}{|c|}{ Bereaved Households } & \multicolumn{2}{|c|}{ Control Households } & \multicolumn{2}{|c|}{ Difference } & \multicolumn{2}{|c|}{ All Households } \\
\hline & Mean & Standard Error & Mean & Standard Error & Mean & $\operatorname{Pr}>|t|$ & Mean & Standard Error \\
\hline \multicolumn{9}{|c|}{ Household Characteristics } \\
\hline Floor size $\left(\mathrm{m}^{2}\right)$ & 71.78 & 2.442 & 68.88 & 1.151 & 2.896 & 0.171 & 65.17 & 0.083 \\
\hline Wall quality high & 0.793 & 0.013 & 0.824 & 0.009 & -0.032 & 0.013 & 0.776 & 0.001 \\
\hline Roof quality high & 0.532 & 0.016 & 0.537 & 0.016 & -0.004 & 0.698 & 0.545 & 0.001 \\
\hline Floor quality high & 0.591 & 0.015 & 0.616 & 0.012 & -0.025 & 0.049 & 0.572 & 0.001 \\
\hline Electricity & 0.652 & 0.014 & 0.672 & 0.013 & -0.020 & 0.082 & 0.667 & 0.001 \\
\hline Private water source & 0.524 & 0.015 & 0.539 & 0.013 & -0.014 & 0.280 & 0.480 & 0.001 \\
\hline Easy-access water source & 0.452 & 0.015 & 0.471 & 0.014 & -0.019 & 0.172 & 0.453 & 0.001 \\
\hline Toilet & 0.342 & 0.015 & 0.359 & 0.014 & -0.016 & 0.185 & 0.349 & 0.001 \\
\hline \multicolumn{9}{|c|}{ Household Composition } \\
\hline Household size & 4.688 & 0.056 & 5.662 & 0.031 & -0.974 & 0.000 & 4.285 & 0.003 \\
\hline No. of children of household head* & 2.787 & 0.045 & 3.171 & 0.027 & -0.384 & 0.000 & 2.822 & 0.004 \\
\hline No. of daughters of household head* & 1.366 & 0.035 & 1.519 & 0.017 & -0.231 & 0.000 & 1.347 & 0.003 \\
\hline No. of sons of household head* & 1.421 & 0.034 & 1.652 & 0.018 & -0.153 & 0.000 & 1.475 & 0.003 \\
\hline \multicolumn{9}{|c|}{ Household Head and Spouse } \\
\hline Primary head is female & 0.676 & 0.014 & 0.001 & 0.000 & 0.675 & 0.000 & 0.127 & 0.001 \\
\hline Age of female head or spouse $(\mathrm{FH})$ & 41.86 & 0.238 & 37.59 & 0.116 & 4.261 & 0.000 & 43.57 & 0.023 \\
\hline Age of male head or spouse (MH) & 48.45 & 0.291 & 43.07 & 0.134 & 5.383 & 0.000 & 39.79 & 0.022 \\
\hline School years, FH 20-39 & 5.190 & 0.160 & 5.877 & 0.103 & 0.686 & 0.000 & 6.270 & 0.008 \\
\hline School years, FH 40-59 & 4.618 & 0.138 & 5.554 & 0.119 & 0.937 & 0.000 & 4.200 & 0.011 \\
\hline School years, FH 60+ & 3.681 & 0.887 & 3.847 & 0.946 & 0.166 & 0.898 & 1.783 & 0.015 \\
\hline School years, MH 20-39 & 6.032 & 0.214 & 6.746 & 0.108 & 0.714 & 0.001 & 7.401 & 0.010 \\
\hline School years, MH 40-59 & 6.342 & 0.144 & 6.984 & 0.126 & 0.642 & 0.000 & 6.185 & 0.011 \\
\hline School years, MH $60+$ & 4.864 & 0.263 & 4.930 & 0.285 & 0.066 & 0.858 & 3.580 & 0.016 \\
\hline No. of observations (HHs) & \multicolumn{2}{|r|}{1,700} & \multicolumn{2}{|r|}{9,133} & & & \multicolumn{2}{|r|}{612,418} \\
\hline
\end{tabular}

* Includes only households where household head has children.

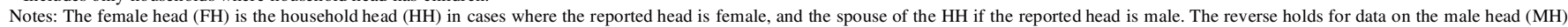
Appendix B provides variable definitions.

construction, access to electricity and plumbing, and many others.

To perform this analysis we took advantage of the fact that the Susenas data were collected by sampling approxi- mately 16 households within an enumeration area-that is, a contiguous set of houses corresponding to roughly a city block. In the discussion below we refer to youth from the same enumeration area as being from the same neighbor-

Table 3.-Monthly Household Consumption of Bereaved, Control, and All Households

\begin{tabular}{|c|c|c|c|c|c|c|c|c|}
\hline & \multicolumn{2}{|c|}{ Bereaved Households } & \multicolumn{2}{|c|}{ Control Households } & \multicolumn{2}{|c|}{ Difference } & \multicolumn{2}{|c|}{ All Households } \\
\hline & Mean & Standard Error & Mean & Standard Error & Mean & $\operatorname{Pr}>|t|$ & Mean & Standard Error \\
\hline \multicolumn{9}{|c|}{ Per Capita Consumption } \\
\hline Food & 28,055 & 665 & 28,292 & 808 & -237 & 0.646 & 30,804 & 36.0 \\
\hline Alcohol and tobacco & 1,925 & 105 & 2,986 & 69 & $-1,061$ & 0.000 & 3,368 & 8.0 \\
\hline Alcohol and tobacco, adult pc & 3,536 & 206 & 5,825 & 129 & $-2,289$ & 0.000 & 5,139 & 11.1 \\
\hline Health and ceremonies & 8,736 & 1,630 & 3,140 & 218 & 5,596 & 0.001 & 3,623 & 60.5 \\
\hline Other nonfood & 19,720 & 1,159 & 22,591 & 2,092 & $-2,871$ & 0.060 & 22,226 & 107.7 \\
\hline All nonfood & 30,381 & 2,147 & 28,717 & 2,198 & 1,664 & 0.464 & 29,217 & 126.9 \\
\hline Total & 58,436 & 2,529 & 57,009 & 2,933 & 1,427 & 0.578 & 60,020 & 144.0 \\
\hline \multicolumn{9}{|c|}{ Household Consumption Shares } \\
\hline Food & 0.586 & 0.005 & 0.588 & 0.004 & -0.003 & 0.499 & 0.595 & 0.000 \\
\hline Tobacco and alcohol & 0.040 & 0.002 & 0.066 & 0.001 & -0.025 & 0.000 & 0.065 & 0.000 \\
\hline Health and ceremonies & 0.301 & 0.017 & 0.183 & 0.006 & 0.118 & 0.000 & 0.179 & 0.001 \\
\hline Other nonfood & 0.073 & 0.015 & 0.163 & 0.006 & -0.090 & 0.000 & 0.161 & 0.001 \\
\hline All nonfood & 0.414 & 0.005 & 0.412 & 0.004 & 0.003 & 0.499 & 0.405 & 0.000 \\
\hline Number of observations (HHs) & \multicolumn{2}{|c|}{1,700} & \multicolumn{2}{|c|}{9,133} & & & \multicolumn{2}{|c|}{612,385} \\
\hline
\end{tabular}

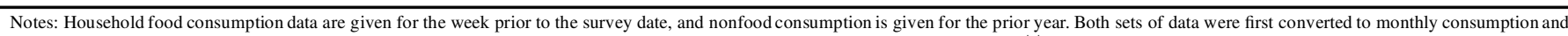

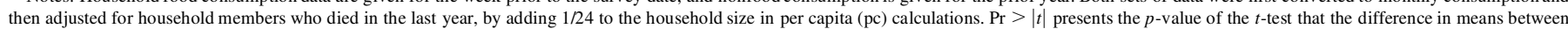
the control and bereaved households is statistically significant. 
hood; given the rural setting for the majority of our sample, it would be equally accurate to refer to them as youth from the same village.

By controlling for neighborhood fixed effects, this model takes account of all factors that are constant within an enumeration area. These factors include neighborhood influences on children, common labor market, distance to a health clinic and school, and many other factors that influence all children in a village or neighborhood.

We estimated the model using the conditional likelihood method suggested in Chamberlain (1980). This method estimates a likelihood function that conditions out the incidental parameter (that is, the neighborhood fixed effects). Specifically, by conditioning on the sum of the probabilities that children in a neighborhood enroll in school, the resulting likelihood function is no longer a function of the neighborhood fixed effects. In this case, the probability that a child $i$ from neighborhood $j$ is enrolled in school is

$$
\operatorname{Prob}\left(E_{i j}=1\right)=\frac{\exp \left(\beta^{\prime} X_{i j}\right)}{\sum_{m=1}^{I_{j}} \exp \left(\beta^{\prime} X_{m j}\right)},
$$

where

$E_{i j}=1$ if child $i$ from neighborhood $j$ is enrolled in school, and 0 otherwise;

$I_{j}=$ number of children in neighborhood $j$;

$X_{i j}=\left(x_{1 i j}, \ldots, x_{n i j}\right)=$ a vector of household and individual characteristics that affect the enrollment of child $i$ from in neighborhood $j$, including whether a parent died last year.

The conditional logit procedure only uses information from neighborhoods where both bereaved and control observations are present and where their enrollment outcomes differed. The neighborhoods in which our data set includes either no control or no bereaved observations add 0 to the likelihood function. We estimate effects separately for each grade.

\section{B. Propensity-Score Matching within a Neighborhood}

Our final set of results uses a propensity-score matching estimator. Unlike fully parametric estimation techniques, this approach does not impose strong restrictions on functional forms. These restrictions are an important limitation on conditional logits, because our sample of children varies widely in key characteristics, even after conditioning for age and education level. The assumption of a logistic function requires a single estimated effect to be calculated from a data set of children who differ widely in individual characteristics, and these characteristics may have different effects depending on their values.

The ideal experiment compares the outcome when two identical individuals are exposed to the same treatment. The propensity-score matching method is an approximation of this experiment. Instead of comparing each treated individual with an exact untreated counterpart, the matching method finds the closest match within a highly comparable subsample of controls.

Here, the closest individual is defined as the one living in the same neighborhood who is most similar to the bereaved observation in the set of characteristics that are significant in determining who loses a parent. Heckman, Ichimura, and Todd (1997) stress the importance of the distribution of the probability coming from the same support. To further test the strength of within-neighborhood matching, we compared these results with those obtained by matching within the entire sample. Although both sets of results support the same conclusions, the full-sample matching results are less consistent (see appendix C).

This propensity score is found by running conditional logits, similar to the ones described above, to estimate the probability of a parent dying in the previous year. We matched each child who lost a parent in the previous year with a control child from a two-parent family. A bereaved child's control is the child in the same neighborhood and four-year age group, with the same level of education, who had the closest propensity score. Research using the matching method has shown that matching on the propensity score may be more powerful and accurate than standard regression techniques, particularly when controlling for region fixed effects (Rosenbaum \& Rubin, 1983; Dehejia \& Wahba, 2002).

\section{Results}

Our first set of results simply compares average enrollment of bereaved children and their neighbors of the same age and sex by age and education group. These results show that the dropout rate for children who have recently lost a parent is significantly higher in almost all age groups than it is for their peers in two-parent households (table 4). The results also suggest that older children's enrollment is more affected by a parent's death. The only exception is if a student has just completed a school level. For example, the difference in enrollment drops from $6.5 \%$ for students who have started, and in many cases finished, the last year of primary school (grade 6), to $5.4 \%$ for students who have begun the first year of junior high school (grade 7). The gap drops again from $9.7 \%$ for students who are in their last year of junior high school (grade 9), to 5.4\% for those who have started senior high school.

Whereas the gap in enrollment increases as students advance within each school level, overall enrollment declines as children get older. The relative dropout rate [ $(\%$ bereaved dropouts $) /(\%$ control dropouts $)]$, therefore, actually declines within each major school level and jumps at the start of new school level. This result implies that bereaved students have a lower risk of being pulled out of school in response to a parent's death as they near completion of a school level. The hazard increases at the beginning 
Table 4.-Difference in Enrollment Rates between Bereaved and Control Age Groups

\begin{tabular}{|c|c|c|c|c|c|c|c|}
\hline \multirow{2}{*}{$\begin{array}{c}\text { Normative } \\
\text { Grade }\end{array}$} & \multicolumn{2}{|c|}{ Bereaved Group } & \multicolumn{2}{|c|}{ Control Group } & \multicolumn{2}{|c|}{ Difference } & \multirow[b]{2}{*}{ Relative Dropout } \\
\hline & Mean & Standard Error & Mean & Standard Error & Mean & $\operatorname{Pr}>|t|$ & \\
\hline 1 & 0.977 & 0.008 & 0.996 & 0.001 & -0.019 & 0.017 & 5.51 \\
\hline 2 & 0.968 & 0.009 & 0.991 & 0.002 & -0.023 & 0.011 & 3.45 \\
\hline 3 & 0.963 & 0.009 & 0.983 & 0.003 & -0.020 & 0.043 & 2.17 \\
\hline 4 & 0.941 & 0.011 & 0.975 & 0.004 & -0.034 & 0.002 & 2.39 \\
\hline 5 & 0.882 & 0.016 & 0.935 & 0.008 & -0.053 & 0.000 & 1.81 \\
\hline 6 & 0.815 & 0.017 & 0.880 & 0.012 & -0.065 & 0.000 & 1.54 \\
\hline 7 & 0.917 & 0.018 & 0.971 & 0.005 & -0.054 & 0.004 & 2.88 \\
\hline 8 & 0.851 & 0.021 & 0.937 & 0.009 & -0.086 & 0.000 & 2.38 \\
\hline 9 & 0.808 & 0.024 & 0.904 & 0.013 & -0.097 & 0.000 & 2.01 \\
\hline 10 & 0.886 & 0.025 & 0.939 & 0.011 & -0.054 & 0.025 & 1.89 \\
\hline 11 & 0.821 & 0.027 & 0.860 & 0.016 & -0.039 & 0.178 & 1.28 \\
\hline 12 & 0.569 & 0.046 & 0.643 & 0.029 & -0.073 & 0.130 & 1.21 \\
\hline
\end{tabular}

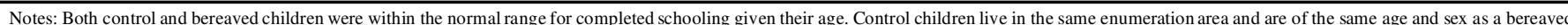

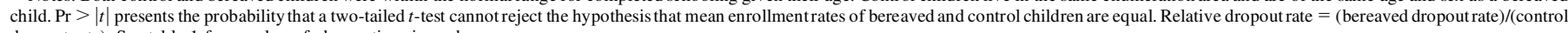
dropout rate). See table 1 for number of observations in each group.

of a school level, possibly because the returns to a year of education are higher if by completing that year the student also completes a new school level. Table 4 shows that the relative dropout rate falls in the fifth and sixth grades, as primary school is ending, and jumps at the beginning of the seventh grade (junior high school). Finally, the relative dropout rate is highest after starting first grade, possibly because it is easier for parents to restart their children in school than to withdraw them and reenroll them after they have completed several years of schooling.

Enrollment comparisons using conditional logits control for household characteristics, such as wealth, which may be inversely correlated with parental death and independently have an impact on school enrollment. Controlling for these factors reduces the impact of parental death on enrollment relative to the difference-in-means results, although the pattern of risk is similar (table 5). Students who are completing a level of schooling (that is, primary school or junior high school) have a lower risk of dropping out, relative to their peers, than students who have started the next level of schooling. Differences in enrollment for students eligible to

Table 5.-The EfFect of a Parent's Death on EnRollment: CONDitional Logit Estimates

\begin{tabular}{|c|c|c|c|c|c|c|}
\hline \multirow{2}{*}{$\begin{array}{c}\text { Normative } \\
\text { Grade }\end{array}$} & \multicolumn{3}{|c|}{ Retained Observations } & \multicolumn{2}{|c|}{$\begin{array}{c}\text { Parent-Died } \\
\text { Coefficient }\end{array}$} & \multirow{2}{*}{$\begin{array}{l}\text { Relative } \\
\text { Dropou }\end{array}$} \\
\hline & Bereaved & Control & Total & $d P / d x$ & $P>|z|$ & \\
\hline 1 & 30 & 136 & 166 & -0.024 & 0.007 & 4.17 \\
\hline 2 & 56 & 267 & 323 & -0.018 & 0.002 & 2.34 \\
\hline 3 & 72 & 345 & 417 & -0.023 & 0.004 & 2.11 \\
\hline 4 & 113 & 487 & 600 & -0.023 & 0.007 & 1.73 \\
\hline 5 & 177 & 653 & 830 & -0.026 & 0.077 & 1.35 \\
\hline 6 & 265 & 848 & 1113 & -0.042 & 0.034 & 1.31 \\
\hline 7 & 81 & 274 & 355 & -0.038 & 0.001 & 1.91 \\
\hline 8 & 129 & 385 & 514 & -0.066 & 0.001 & 1.78 \\
\hline 9 & 149 & 424 & 573 & -0.074 & 0.001 & 1.62 \\
\hline 10 & 69 & 154 & 223 & 0.014 & 0.617 & 0.82 \\
\hline 11 & 121 & 299 & 420 & -0.038 & 0.254 & 1.25 \\
\hline 12 & 133 & 296 & 429 & -0.069 & 0.237 & 1.18 \\
\hline
\end{tabular}

Dependent variable: enrollment.

Notes: Additional control variables are listed in appendix B. Relative dropout rate $=$ (bereaved dropout rate)/(control dropout rate). Sample sizes are smaller than in other analyses because only enumeration areas with bereaved and control children whose dropout status differed are retained in the conditional logit analysis. be in grades 10 and above are insignificant in the conditional logit results.

The results of table 5 are also expressed as the relative dropout, which is in the last column. Bereaved families are over 4 times more likely to fail to enroll a child entering first grade than a similar child in a control (two-parent) family. A child in the last grade of high school who loses a parent is 1.2 times as likely to fail to enroll as a control child. Averaging over all grades, a bereaved child is 1.8 times as likely to stop school as a control child.

The matching approach removes the functional-form restrictions imposed by the conditional logit results. Comparing bereaved children with controls with the closest propensity score, however, yields similar results to the parametric approach (table 6): the hazard again decreases fairly consistently with age through sixth grade, increases after children start junior high, and declines again until senior high school. Overall, a child whose parent died last year is 2.0 times more likely to drop out of school than a peer.

When we compare the relative dropout rates calculated using the three approaches, we again see that the pattern of the effect is similar in all three cases, although the magnitude of the effect is generally smaller when household characteristics have been controlled for (see figure 1). That the standard statistical analysis (conditional logit, table 5) and matching estimates (table 6) are similar in pattern and magnitude increases our confidence in these results.

\section{A. Imperfect Capital Markets}

The results in tables 4 through 6 reject the hypothesis, based on the assumption of perfect capital markets, that enrollment is unaffected by parental loss. To further test the relationship between liquidity constraint and the effect of a parent's death, we ran our conditional logit model again, this time including an interaction with parent death and an index of advantage.

To create the index of advantage, we estimated consumption as a function of surviving parent's education, average neighborhood consumption, family composition, and house- 
Table 6.-The Effect of a Parent's Death on Enrollment: Matching Technique Estimates

\begin{tabular}{|c|c|c|c|c|c|c|c|c|c|c|c|}
\hline \multirow[b]{2}{*}{$\begin{array}{c}\text { Normative } \\
\text { Grade }\end{array}$} & \multicolumn{5}{|c|}{ Who Is Enrolled in Each Pair? } & \multicolumn{4}{|c|}{ Proportion of Children Enrolled } & \multicolumn{2}{|c|}{ Dropout Statistics } \\
\hline & $\begin{array}{c}\text { Control + } \\
\text { Bereaved }\end{array}$ & $\begin{array}{c}\text { Control } \\
\text { Only }\end{array}$ & $\begin{array}{c}\text { Bereaved } \\
\text { Only }\end{array}$ & Neither & $\begin{array}{l}\text { Total } \\
\text { Pairs }\end{array}$ & Control & Bereaved & Diff. & $\operatorname{Pr}>|t|$ & $\begin{array}{l}\text { Odds } \\
\text { Ratio }\end{array}$ & $\begin{array}{l}\text { Relative } \\
\text { Dropout }\end{array}$ \\
\hline 1 & 727 & 14 & 4 & 0 & 745 & 0.994 & 0.977 & -0.017 & 0.041 & 0.286 & 3.93 \\
\hline 2 & 752 & 21 & 13 & 2 & 788 & 0.986 & 0.968 & -0.018 & 0.055 & 0.619 & 2.27 \\
\hline 3 & 707 & 26 & 16 & 1 & 750 & 0.981 & 0.963 & -0.018 & 0.086 & 0.615 & 1.94 \\
\hline 4 & 748 & 41 & 17 & 3 & 809 & 0.973 & 0.941 & -0.032 & 0.019 & 0.415 & 2.16 \\
\hline 5 & 656 & 69 & 31 & 15 & 771 & 0.935 & 0.882 & -0.053 & 0.005 & 0.449 & 1.81 \\
\hline 6 & 591 & 94 & 55 & 43 & 783 & 0.861 & 0.815 & -0.045 & 0.051 & 0.585 & 1.33 \\
\hline 7 & 499 & 34 & 12 & 3 & 548 & 0.964 & 0.917 & -0.047 & 0.028 & 0.353 & 2.30 \\
\hline 8 & 426 & 51 & 26 & 10 & 513 & 0.925 & 0.851 & -0.073 & 0.006 & 0.510 & 1.97 \\
\hline 9 & 321 & 66 & 35 & 15 & 437 & 0.881 & 0.808 & -0.073 & 0.019 & 0.530 & 1.61 \\
\hline 10 & 254 & 24 & 20 & 9 & 307 & 0.931 & 0.886 & -0.045 & 0.104 & 0.833 & 1.65 \\
\hline 11 & 196 & 45 & 34 & 17 & 292 & 0.883 & 0.821 & -0.062 & 0.075 & 0.756 & 1.53 \\
\hline 12 & 82 & 51 & 39 & 53 & 225 & 0.570 & 0.569 & 0.000 & 0.995 & 0.765 & 1.00 \\
\hline
\end{tabular}

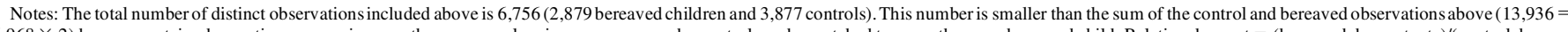

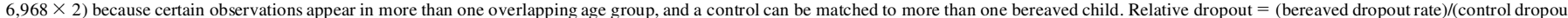

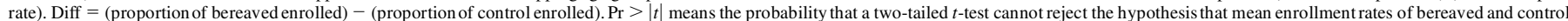
children are equal. The percentage enrolled and following calculations are slightly different from the percentages derived directly from the counts because the percent enrolled uses sample weights.

hold construction quality. The predicted value from this equation is a sensible measure of a family's permanent income. In a situation where borrowing is often difficult, high estimated consumption also correlates with high current assets. On average, we expect families with a high index of advantage (that is, predicted consumption) to be less likely to face liquidity constraints after a negative income shock.

As the results in table 7 show, high-asset families do not experience a smaller effect of parental death. The interaction term is small and not statistically significant. Thus, there is no evidence that children in households with preexisting advantages suffer smaller enrollment declines after losing a parent.

\section{B. Sons versus Daughters}

Theories of intrahousehold allocation suggest that daughters, especially eldest daughters, will be particularly disadvantaged after the loss of a parent. Moreover, if sons are favored, then losing a parent is more costly to children if they have many brothers than if they have many sisters.

Figure 1.-Relative Dropout Rates: Comparison of Three Methods

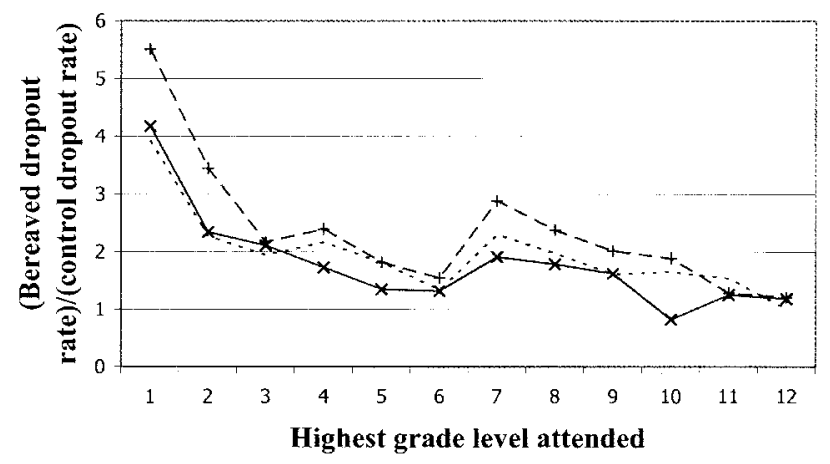

-+- Difference in Means $x$ Conditional Logit $\cdots \cdots$ Matching
Although it is not true that daughters are more likely to drop out than are sons, it is true that eldest daughters who have younger siblings are more likely to drop out than are sons. This result is consistent with the hypothesis that the eldest daughter steps in to perform childcare and housework after a parent dies. After seeing these results, we realized they might hold largely after loss of a mother, as a daughter's labor may be a better substitute for her mother's work than for her father's. In results not shown, the effect on oldest daughters was not statistically significantly larger if her mother died than if her father died.

Finally, the proportion of siblings who are brothers has no effect on the increased rate of dropping out by children who lose a parent. These results were similar when we added interactions separately for each grade level (results available on request).

\section{Loss of a Mother versus a Father}

If fathers' higher average earnings play a larger role in children's education than do mothers' traditional larger role

Table 7.-The Effect of the Interaction between High Assets and Parental Loss on EnRollment: Conditional Logit Estimates

\begin{tabular}{lrrr}
\hline \hline \multicolumn{1}{c}{ No. of observations } & \multicolumn{3}{c}{8,575} \\
LR $\chi^{2}(42)$ & \multicolumn{3}{c}{1,694} \\
Prob $>\chi^{2}$ & \multicolumn{3}{c}{$-1,599$} \\
Log likelihood & Coeff. & Std. Err. & $P>|z|$ \\
\multicolumn{1}{c}{ Independent Variable } & -1.081 & 0.241 & 0.000 \\
Parent died & 4.387 & 0.627 & 0.000 \\
Advantage index & 0.345 & 0.276 & 0.212 \\
(Parent died) $\times$ (advantage index) & 0.017 & 0.051 & 0.745 \\
No. of siblings & -0.008 & 0.137 & 0.952 \\
Son & -0.224 & 0.125 & 0.072 \\
Oldest son & -0.359 & 0.124 & 0.004 \\
Oldest daughter &
\end{tabular}

Notes: Dependent variable: enrollment. Additional control variables include number of siblings, mother's and father's ages, house characteristics, whether the child was the oldest son or oldest daughter, child age and education group dummies, and these dummies interacted with parent-died dummy. The index of advantage is predicted consumption based on a regression controlling for the surviving parent's education, average neighborhood consumption, family composition, and household construction quality. 
TABle 8.- Intrahousehold Results: Conditional LOGIT Estimates

\begin{tabular}{|c|c|c|c|c|c|c|c|}
\hline \multirow[b]{2}{*}{ Independent Variable } & \multicolumn{6}{|c|}{ Specification: } & \multirow[b]{2}{*}{ Mean } \\
\hline & $\begin{array}{c}\mathrm{A} \\
d P / d x\end{array}$ & $\begin{array}{c}\mathrm{B} \\
d P / d x\end{array}$ & $\begin{array}{c}\mathrm{C} \\
d P / d x\end{array}$ & $\begin{array}{c}\mathrm{D} \\
d P / d x\end{array}$ & $\begin{array}{c}\mathrm{E} \\
d P / d x\end{array}$ & $\begin{array}{c}\mathrm{F} \\
d P / d x\end{array}$ & \\
\hline Parent died & $\begin{array}{r}-0.001 \\
0.987\end{array}$ & $\begin{array}{r}-0.005 \\
0.927\end{array}$ & $\begin{array}{r}-0.020 \\
0.743\end{array}$ & $\begin{array}{r}-0.025 \\
0.678\end{array}$ & $\begin{array}{r}-0.022 \\
0.713\end{array}$ & $\begin{array}{r}-0.024 \\
0.696\end{array}$ & $\begin{array}{l}0.179 \\
0.383\end{array}$ \\
\hline Daughter & $\begin{array}{r}-0.007 \\
0.323\end{array}$ & $\begin{array}{r}-0.013 \\
0.122\end{array}$ & $\begin{array}{r}-0.014 \\
0.096\end{array}$ & $\begin{array}{r}-0.013 \\
0.129\end{array}$ & $\begin{array}{r}-0.013 \\
0.126\end{array}$ & $\begin{array}{r}-0.013 \\
0.129\end{array}$ & $\begin{array}{l}0.485 \\
0.500\end{array}$ \\
\hline Daughter $\times$ (parent died) & $\begin{array}{l}0.002 \\
0.906\end{array}$ & $\begin{array}{l}0.027 \\
0.105\end{array}$ & $\begin{array}{l}0.027 \\
0.098\end{array}$ & $\begin{array}{l}0.028 \\
0.096\end{array}$ & $\begin{array}{l}0.028 \\
0.092\end{array}$ & $\begin{array}{l}0.035 \\
0.063\end{array}$ & $\begin{array}{l}0.087 \\
0.282\end{array}$ \\
\hline Oldest & $\begin{array}{r}-0.027 \\
0.000\end{array}$ & $\begin{array}{r}-0.029 \\
0.000\end{array}$ & $\begin{array}{r}-0.032 \\
0.000\end{array}$ & $\begin{array}{r}-0.030 \\
0.000\end{array}$ & $\begin{array}{r}-0.030 \\
0.000\end{array}$ & $\begin{array}{r}-0.030 \\
0.000\end{array}$ & $\begin{array}{l}0.375 \\
0.484\end{array}$ \\
\hline Oldest daughter & & $\begin{array}{l}0.013 \\
0.213\end{array}$ & $\begin{array}{l}0.014 \\
0.157\end{array}$ & $\begin{array}{l}0.012 \\
0.237\end{array}$ & $\begin{array}{l}0.012 \\
0.234\end{array}$ & $\begin{array}{l}0.012 \\
0.237\end{array}$ & $\begin{array}{l}0.226 \\
0.419\end{array}$ \\
\hline$($ Oldest daughter $) \times($ parent died $)$ & & $\begin{array}{r}-0.050 \\
0.010\end{array}$ & $\begin{array}{r}-0.053 \\
0.007\end{array}$ & $\begin{array}{r}-0.057 \\
0.004\end{array}$ & $\begin{array}{r}-0.058 \\
0.004\end{array}$ & $\begin{array}{r}-0.058 \\
0.004\end{array}$ & $\begin{array}{l}0.035 \\
0.183\end{array}$ \\
\hline Siblings & & & $\begin{array}{r}-0.008 \\
0.023\end{array}$ & $\begin{array}{r}-0.009 \\
0.017\end{array}$ & $\begin{array}{r}-0.009 \\
0.016\end{array}$ & $\begin{array}{r}-0.009 \\
0.016\end{array}$ & $\begin{array}{l}3.516 \\
1.521\end{array}$ \\
\hline Siblings $\times($ parent died $)$ & & & $\begin{array}{l}0.005 \\
0.286\end{array}$ & $\begin{array}{l}0.004 \\
0.444\end{array}$ & $\begin{array}{l}0.004 \\
0.438\end{array}$ & $\begin{array}{l}0.004 \\
0.436\end{array}$ & $\begin{array}{l}0.601 \\
1.442\end{array}$ \\
\hline Brothers & & & & $\begin{array}{l}0.007 \\
0.452\end{array}$ & $\begin{array}{l}0.007 \\
0.451\end{array}$ & $\begin{array}{l}0.007 \\
0.450\end{array}$ & $\begin{array}{l}0.483 \\
0.363\end{array}$ \\
\hline Brothers $\times$ (parent died $)$ & & & & $\begin{array}{l}0.022 \\
0.259\end{array}$ & $\begin{array}{l}0.022 \\
0.265\end{array}$ & $\begin{array}{l}0.022 \\
0.263\end{array}$ & $\begin{array}{l}0.083 \\
0.238\end{array}$ \\
\hline Mother died & & & & & $\begin{array}{l}-0.008 \\
-0.580\end{array}$ & $\begin{array}{l}0.001 \\
0.943\end{array}$ & $\begin{array}{l}0.058 \\
0.233\end{array}$ \\
\hline Daughter $\times($ mother died $)$ & & & & & & $\begin{array}{r}-0.020 \\
0.428\end{array}$ & $\begin{array}{l}0.029 \\
0.168\end{array}$ \\
\hline
\end{tabular}

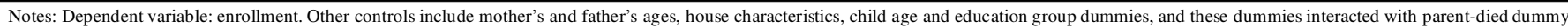

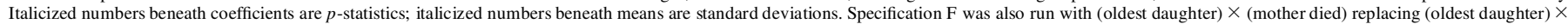
(parent died). The coefficient in this case was not significant. Number of observations: 17,434.

in child rearing and tying to social networks, then we would expect the loss of a father to have a larger effect on children's education than the loss of a mother. In fact, when we ran a pooled conditional logit with age and education dummies, there is no statistically significant difference in the effect of maternal and paternal mortality (table 8, specification E). When we reran the analysis interacting paternal loss with each grade, we found that paternal loss mattered slightly more for elementary school continuation than for higher grades (results available on request). Finally, maternal and paternal loss did not appear to have a larger effect on own-sex children (specification F).

\section{Potential Biases}

Although the methodologies we used are designed to minimize bias, a number of unobserved characteristics remain that can bias the results, and gaps in the data may distort the results as well. For several reasons most of these potential biases reduce the estimated magnitude of the effect of parental death on child enrollment. Thus, the true effect of losing a parent is probably larger than our estimates.

First, because Susenas only allows us to link household heads with their children, we are not able to capture the effect of a shock on children whose parents are not the head of the household in which they live. Therefore, children sent to live with relatives or other families after a parent's death cannot be included in the bereaved group, and children who lose both parents in one year are by definition not the child of any household head. These children may be at greater risk of dropping out of school, and therefore omitting them reduces our estimates.

Second, Susenas only surveys children living in households. This means that our data does not include street children or children living in institutions such as orphanages. Children who have lost a parent are at above-average risk of leaving the Susenas sample for nonstandard arrangements. Thus, missing such children is probably more likely after a parent dies, and missing them will probably cause us to underestimate the reduction in child welfare following loss of a parent.

Third, a parent's death is sometimes preceded by a long illness. If that illness reduced child enrollments prior to death, then the decline in enrollment after parental death we measure is lower than the decline in enrollment due to illness plus death.

Working in the other direction, if the survey is taken during a transitory period after the death of a parent, we may overestimate the gap in enrollment due to this shock. A child 
and the family may be traumatized, be busy with the funeral, be preparing to move, or have just moved and not yet reenrolled in school.

We investigate the importance of two of these potential biases using longitudinal data from the Indonesia Family Life Surveys (IFLS). First, do we miss many children in the Susenas sample? Second, were families that would soon lose a parent already severely disadvantaged prior to parental death? The IFLS is a panel survey of over 7,000 households representative of $83 \%$ of the population conducted in 1994 and in 1998.

\section{A. Do Most Children Who Lose a Parent Live with a Surviving Parent?}

Among 5,488 children aged 6 to 15 in the 1997 IFLS, 140 children lost 91 parents between 1993 and 1997. Of this sample, none lost both parents the same year. Although some Indonesian children do lose both parents within a year, the rarity of this event is reassuring, because it implies we are not missing too many children who lost both parents when we examine the Susenas, with its one-year recall.

In $4 \%$ of the cases, a bereaved child who lost a parent between 1993 and 1997 moved to a new household without his or her remaining parent by 1997 . When such moves happened in the year after losing a parent, the Susenas data set would not identify that child as having lost a parent. In addition, in another $1.4 \%$ of the cases, both the parent and child left their 1993 household, and we could not determine if they were living together in 1997. Presumably if the Susenas included information on bereaved children who were fostered out (or living in orphanages and other institutions), enrollments would be seen to decline more than we measure. Fortunately, such occurrences appear to be rare in Indonesia, so our results are probably fairly accurate.

\section{B. Do Serious Health Problems Usually Predate Death?}

It is possible that most parental deaths are preceded by long periods of ill health. Such ill health can both reduce ability to pay and increase the value of a child's work at home caring for siblings of the ailing adult. Thus, we were also concerned that enrollment might be depressed in families that were soon to lose a parent prior to the parental death. If this effect were strong, our estimates of the effects of parental death on school enrollments might seriously underestimate the true effects of ill health and death combined.

To test for the importance of this factor, we examined the health in 1993 of parents who died between 1993 and 1997. Our measure of health is an index of an individual's selfreported ability to physically perform activities of daily living (ADLs): to carry a heavy load for 20 meters; sweep the floor or yard; walk for 5 kilometers; take water from a well; and bend, kneel, or stoop. These self-reported physical functioning measures have shown high reliability and va- lidity in both the United States and East Asian countries (Andrews et al., 1986; Guralnik et al., 1989; Ju \& Jones, 1989; Strauss et al., 1993; Ware, Davies-Avery, \& Brook, 1980).

Parents who would die by 1997 already had slightly worse health in 1993 than those that would live to 1997, but the differences are small and not significant. For example, of five activities of daily living such as walking 2 kilometers, $89.9 \%$ of parents who would live and $82.9 \%$ of those who would soon die could perform all of them easily.

Parents who would soon die are a few years older on average than other parents. Moreover, age strongly correlates with worse health in Indonesia. Thus, it is important to control for this and other factors when examining if parents who would soon die were particularly disadvantaged prior to their death. In fact, when we control for island-group residence, urban residence, mean village consumption, and household composition, none of the health differences are statistically significantly different between parents who would soon die and those that would live past $1997 .{ }^{8}$

In short, deaths of parents of school-aged Indonesian children appear to be largely surprises. Results in nations with high rates of HIV/AIDS or the elderly (where cancers and general frailty are more prevalent) might be very different.

\section{Conclusions}

The basic result of this paper is that a recent parent's death reduces children's enrollment in Indonesia. This effect is largest for youth at the transitions between primary and junior secondary and between junior secondary and secondary. Our results are more convincing than past findings for two reasons. First, we use both parametric and seminonparametric methods. Second, we have a much larger sample size than most prior research on this topic.

Our findings have important implications for children of bereaved families in developing countries. In 1999, approximately 2.2 million Indonesian children under the age of fifteen were living with a widowed parent. ${ }^{9}$ Our results indicate that children in such families leave school at roughly $50 \%$ higher rates than do their classmates. Given the high returns to education in Indonesia, even at primary levels, and the high percentage of families living at or below the poverty level, this loss in schooling could substantially reduce the future living standard of these children.

It is possible that some of the lower enrollment we observe is due to family's efficiently reducing expenditures on education that is largely for consumption and efficiently reallocating time use as the marginal costs and benefits of schooling shift. At the same time, if the reduction in family income, coupled with liquidity constraints, drives the lower enrollment of bereaved children, then the government may

\footnotetext{
${ }^{8}$ The results of this analysis are available on request.

${ }^{9}$ Susenas, 1999.
} 
have a role in providing socially funded life insurance and in promoting the growth of formal and informal insurance mechanisms. Moreover, when targeting scholarships or other assistance to children, having lost a parent may be a good signal of deprivation and the potential for high returns. Donors to poor nations may want to target assistance at children who have lost a parent, particularly orphans. The HIV/AIDS crisis is leading to rising death rates for parents of children in many nations, and the policy response to supporting bereaved school-aged children will be increasingly important for policymakers in many nations.

Although our research shows a substantial short-term impact of a parent's death on enrollment, additional work is needed to identify the long-term effects. For example, a parent's death may lead to a child's temporary exit from school due to a change in residence or short-term work requirements until the household's income stream is stabilized. Depending on the length of time away from school and the probability of reenrollment, the long-term effect on a child's schooling could vary dramatically. Although determining the magnitude of this effect is not within the scope of this study, it is an important issue for future research.

Additionally, improved data would be useful to better capture the direct effect of parental loss on enrollment. Because our data set is not a true panel, it does not include information on children's enrollment status prior to their parent's death. Although we used several methods to infer the enrollment status of children before their parent's death, the variation in the age at which children start school in Indonesia makes it impossible to be fully confident in our assumptions.

\section{REFERENCES}

Ainsworth, Martha, Kathleen Beegle, and Godlike Koda, "The Impact of Adult Mortality on Primary School Enrollment in Northwestern Tanzania," UNAIDS Africa Development Forum paper (Washington, DC: The World Bank, 2000).

Alderman, H., and P. Gertler, "Family Resources and Gender Differences in Human Capital Investments: The Demand for Children's Medical Care in Pakistan," in L. Haddad, J. Hoddinott, and H. Alderman (Eds.), Intrahousehold Resource Allocation in Developing Countries (Baltimore, MD: The Johns Hopkins University Press, 1997).

Andrews, Gary, Adrian Esterman, Annette Braunack-Mayer, and Cam Rungie, Aging in the Western Pacific (Manila: World Health Organization, 1986).

Astone, Nan Marie, and Sara S. McLanahan, "Family Structure, Parental Practices and High School Completion," American Sociological Review 56 (1991), 309-320.

Becker, Gary, and Nigel Tomes, "An Equilibrium Theory of the Distribution of Income and Intergenerational Mobility," Journal of Political Economy 86:6 (1979), 1153-1158.

"Human Capital and the Rise and Fall of Families," Journal of Labor Economics 4:3 (1986), S1-S39.

Cameron, L. A., and C. Worswick. "Education Expenditure Responses to Crop Loss in Indonesia: A Gender Bias," Economic Development and Cultural Change 49:2 (2001), 351-363.

Chamberlain, Gary, "Analysis of Covariance with Qualitative Data," The Review of Economic Studies 47:1 (1980), 225-238.

Copson, Raymond W. "AIDS in Africa," CRS Issue Brief for Congress, IB 10050, Washington, DC: Congressional Research Service, Library of Congress (updated April 9, 2002).
Datcher-Loury, Linda, "Effects of Mother's Home Time on Children's Schooling," this REVIEW, 70 (1988), 367-373.

Dehejia, Rajeev H., and Sadek Wahba, "Propensity Score Matching Methods for Non-experimental Causal Studies," this REvIEW, 84 (2002), 151-161.

Downey, Douglas B., "The School Performance of Children from SingleMother and Single-Father Families," Journal of Family Issues 5:1 (1994), 129-147.

Drèze, Jean, and Amartya Sen, Hunger and Public Action (Oxford, England: Clarendon Press, 1989).

Garg, Ashish, and Jonathan Morduch, "Sibling Rivalry and the Gender Gap: Evidence from Child Health Outcomes in Ghana," Journal of Population Economics 11:4 (1998), 471-493.

Geertz, Hildred, The Javanese Family: A Study of Kinship and Socialization (New York: Free Press of Glencoe, 1961).

Indonesian Cultures and Communities (New Haven, CT: HRAF Press, 1963).

Government of Indonesia, Ministry of Education and Culture, Education Development in Indonesia: A Country Report (Jakarta, 1996).

Guralnik, J., L. Branch, S. Cummings, and J. Curb, "Physical Performance Measures in Aging Research," Journal of Gerontology 44 (1989), 141-146.

Haddad, L., and J. Hoddinott, "Women's Income and Boy-Girl Anthropometric Status in the Côte d'Ivoire," World Development 22:4 (1994), 543-553.

Haddad, Lawrence, John Hoddinott, and Harold Alderman (Eds.), Intrahousehold Resource Allocation in Developing Countries (Baltimore, MD: The Johns Hopkins University Press, 1997).

Haveman, Robert H., and Barbara L. Wolfe, "The Determinants of Children's Attainments: A Review of Methods and Findings," Journal of Economic Literature 33 (1995), 1829-1878.

Heckman, James J., Hidehiko Ichimura, and Petra E. Todd, "Matching as an Econometric Evaluation Estimator: Evidence from Evaluating a Job Training Programme," The Review of Economic Studies 64:4 (1997), 605-654.

Hetherington, E. M., K. A. Camara, and D. L. Featherman, “Achievement and Intellectual Functioning of Children in One-Parent Households," in J. T. Spence (Ed.), Achievement and Achievement Motives: Psychological and Sociological Approaches (San Francisco: Freeman, 1983).

Hill, Martha, and Greg Duncan, "Parental Family Income and the Socioeconomic Attainment of Children," Social Science Research 16 (1987), 39-73.

Hunter, Susan, and John Williamson, Children on the Brink 2000: Updated Estimates and Recommendations for Intervention, Washington, DC: USAID/The Synergy Project, executive summary (2000).

Jellinek, Lea, The Wheel of Fortune: The History of a Poor Community in Jakarta (Honolulu: University of Hawaii Press, 1991).

$\mathrm{Ju}$, Chen A., and Gavin Jones, Aging in ASEAN and its Socio-economic Consequences (Singapore: Institute of Southeast Asian Studies, 1989).

Kevane, Michael, and David I. Levine, "The Changing Status of Daughters in Indonesia," University of California, Berkeley, mimeograph (2002).

Krein, Sheila F., and Andrea H. Beller, "Educational Attainment of Children from Single-Parent Families: Differences by Exposure, Gender, and Race,” Demography 25 (1988), 221-234.

Leibowitz, Arleen, "Home Investments in Children," The Journal of Political Economy 82 (1974), S111-S131.

Levine, David, and Gary Painter, "The Costs of Teenage Out-of-Wedlock Childbearing: Analysis with a Within-School Propensity Score Matching Estimator," Institute of Industrial Relations working paper no. 74, University of California, Berkeley (2000).

Lloyd, Cynthia, and Ann K. Blanc, "Children's Schooling in Sub-Saharan Africa," Population and Development Review 22:2 (1996), 265-298.

Manderson, L. (Ed.), Women's Work and Women's Roles: Economics and Everyday Life in Indonesia, Malaysia and Singapore (Canberra, Australia: The Australian National University, 1983).

Mayer, Susan E., What Money Can't Buy: Family Income and Children's Life Chances (Cambridge, MA: Harvard University Press, 1997).

McLanahan, Sara S., "Family Structure and the Reproduction of Poverty," American Journal of Sociology 90 (1985), 873-901. 
Pong, Suet-Ling, "Family Structure, School Context and Eighth-Grade Math and Reading Achievement," Journal of Marriage and the Family 59:3 (1997), 734-746.

Reid, Elizabeth, "Children in Families Affected by the HIV Epidemic: A Strategic Approach," UNDP HIV and Development Programme issues paper no. 13 (1993).

Rose, Elaina, "Consumption Smoothing and Excess Female Mortality in Rural India," this REVIEW, 81:1 (1999), 41-49.

Rosenbaum, Paul R., and Donald B. Rubin, "The Central Role of the Propensity Score in Observational Studies for Causal Effects," Biometrika 70:1 (1983), 41-55.

Steelman, Lala Carr, and James A. Mercy, "Unconfounding the Confluence Model: A Test of Sibship Size and Birth-Order Effects on Intelligence," American Sociological Review 45 (1980), 571-582.

Strauss, John, Paul Gertler, Omar Rahman, and Kristin Fox, "Gender and Life-Cycle Differentials in the Patterns and Determinants of Adult Health," Journal of Human Resources 28 (1993), 791-837.

Sullivan, Norma, Masters and Managers: A Study of Gender Relations in Urban Java (St. Leonards, NSW, Australia: Allen \& Unwin, 1994).

Surbakti, Pajung, Indonesia's National Socio-Economic Survey: A Continual Data Source for Analysis on Welfare Development (Jakarta: Central Bureau of Statistics, 1997).

Thomas, Duncan, "Income, Expenditure and Health Outcomes: Evidence on Intrahousehold Resource Allocation," in L. Haddad, J. Hoddinott, and H. Alderman (Eds.), Intrahousehold Resource Allocation in Developing Countries (Baltimore, MD: The Johns Hopkins University Press, 1997).

Townsend, Robert. "Risk and Insurance in Village India," Econometrica $62: 3$ (1994), 539-591.

"Consumption Insurance: An Evaluation of Risk-Bearing Systems in Low-Income Economies," Journal of Economic Perspectives 9:3 (1995), 83-102.

Ware, John E., Allyson Davies-Avery, and Robert H. Brook, Conceptualization and Measurement of Health for Adults in the Health Insurance Study: Volume IV, Analysis of Relationships among Health Status Measures, R-1987/6-HEW (Santa Monica, CA: RAND, 1980).

World Bank, Confronting AIDS: Public Priorities in a Global Epidemic, revised ed. (New York: Oxford University Press, 1999).

\section{APPENDIX A}

Percentage of Students in Each Grade, by Age

\begin{tabular}{|c|c|c|c|c|c|c|c|c|c|c|c|c|}
\hline \multirow[b]{3}{*}{ Age } & \multicolumn{12}{|c|}{ Percentage } \\
\hline & \multicolumn{6}{|c|}{ Primary School } & \multicolumn{3}{|c|}{ Junior High } & \multicolumn{3}{|c|}{ Senior High } \\
\hline & Grade 1 & 2 & 3 & 4 & 5 & 6 & 7 & 8 & 9 & 10 & 11 & 12 \\
\hline 5 & 2 & 0 & 0 & 0 & 0 & 0 & 0 & 0 & 0 & 0 & 0 & 0 \\
\hline 6 & 26 & 1 & 0 & 0 & 0 & 0 & 0 & 0 & 0 & 0 & 0 & 0 \\
\hline 7 & 51 & 18 & 1 & 0 & 0 & 0 & 0 & 0 & 0 & 0 & 0 & 0 \\
\hline 8 & 14 & 47 & 15 & 1 & 0 & 0 & 0 & 0 & 0 & 0 & 0 & 0 \\
\hline 9 & 3 & 24 & 44 & 14 & 1 & 0 & 0 & 0 & 0 & 0 & 0 & 0 \\
\hline 10 & 1 & 6 & 29 & 45 & 15 & 1 & 0 & 0 & 0 & 0 & 0 & 0 \\
\hline 11 & 1 & 1 & 7 & 26 & 41 & 14 & 1 & 0 & 0 & 0 & 0 & 0 \\
\hline 12 & 1 & 1 & 3 & 9 & 30 & 47 & 18 & 2 & 0 & 0 & 0 & 0 \\
\hline 13 & 0 & 0 & 1 & 3 & 9 & 27 & 45 & 18 & 2 & 0 & 0 & 0 \\
\hline 14 & 0 & 0 & 0 & 1 & 3 & 8 & 25 & 44 & 18 & 2 & 0 & 0 \\
\hline 15 & 0 & 0 & 0 & 0 & 1 & 2 & 7 & 25 & 46 & 19 & 2 & 0 \\
\hline 16 & 0 & 0 & 0 & 0 & 0 & 1 & 2 & 7 & 24 & 49 & 23 & 3 \\
\hline 17 & 0 & 0 & 0 & 0 & 0 & 0 & 1 & 2 & 7 & 22 & 47 & 23 \\
\hline 18 & 0 & 0 & 0 & 0 & 0 & 0 & 0 & 1 & 2 & 6 & 20 & 42 \\
\hline 19 & 0 & 0 & 0 & 0 & 0 & 0 & 0 & 0 & 1 & 2 & 5 & 21 \\
\hline 20 & 0 & 0 & 0 & 0 & 0 & 0 & 0 & 0 & 0 & 1 & 2 & 7 \\
\hline 21 & 0 & 0 & 0 & 0 & 0 & 0 & 0 & 0 & 0 & 0 & 0 & 2 \\
\hline 22 & 0 & 0 & 0 & 0 & 0 & 0 & 0 & 0 & 0 & 0 & 0 & 1 \\
\hline Total & 100 & 100 & 100 & 100 & 100 & 100 & 100 & 100 & 100 & 100 & 100 & 100 \\
\hline Sum & 94 & 95 & 94 & 95 & 95 & 95 & 96 & 95 & 95 & 95 & 95 & 94 \\
\hline
\end{tabular}

Bold percentages represent students are considered age-appropriate for that grade.

\section{APPENDIX B}

\section{Control Variables Used in Conditional Logit Regressions}

No. of siblings, self included

1 if male

1 if oldest son

1 if oldest daughter

Mother's age

Father's age

Household size

$\log$ (floor size)

Wall quality: 1 if walls made from strong material (brick or wood)

Roof quality high: 1 if roof made from strong material (concrete, wood, or tile)

Floor quality high: 1 if floors made from strong material (marble, ceramic, or brick)

Electricity: 1 if household has access to electricity

Private water source: 1 if private water source

Easy-access water source: 1 if household has protected and nearby water source

Toilet: 1 if household has a toilet 


\section{APPENDIX C}

Comparison of Matching within the Entire Sample and within the Enumeration Area

Table C1.-Matching Technique Estimates: Best Match within Sample

\begin{tabular}{|c|c|c|c|c|c|c|c|c|c|c|c|}
\hline \multirow[b]{2}{*}{$\begin{array}{l}\text { Normative } \\
\text { Grade }\end{array}$} & \multicolumn{5}{|c|}{ Who Is Enrolled in Each Pair? } & \multicolumn{4}{|c|}{ Proportion of Children Enrolled } & \multicolumn{2}{|c|}{ Dropout Statistics } \\
\hline & $\begin{array}{c}\text { Control }+ \\
\text { Bereaved }\end{array}$ & $\begin{array}{l}\text { Control } \\
\text { Only }\end{array}$ & $\begin{array}{c}\text { Bereaved } \\
\text { Only }\end{array}$ & Neither & $\begin{array}{l}\text { Total } \\
\text { Pairs }\end{array}$ & Control & Bereaved & Diff. & $\operatorname{Pr}>|t|$ & $\begin{array}{l}\text { Odds } \\
\text { Ratio }\end{array}$ & $\begin{array}{l}\text { Relative } \\
\text { Dropout }\end{array}$ \\
\hline 1 & 731 & 14 & 0 & 0 & 745 & 1.000 & 0.977 & -0.023 & 0.00 & 0.000 & - \\
\hline 2 & 758 & 23 & 7 & 0 & 788 & 0.994 & 0.968 & -0.026 & 0.00 & 0.304 & 5.28 \\
\hline 3 & 720 & 27 & 3 & 0 & 750 & 0.995 & 0.963 & -0.032 & 0.00 & 0.111 & 7.91 \\
\hline 4 & 731 & 42 & 34 & 2 & 809 & 0.960 & 0.941 & -0.019 & 0.14 & 0.810 & 1.49 \\
\hline 5 & 635 & 76 & 52 & 8 & 771 & 0.929 & 0.882 & -0.047 & 0.01 & 0.684 & 1.67 \\
\hline 6 & 557 & 118 & 89 & 19 & 783 & 0.867 & 0.815 & -0.052 & 0.02 & 0.754 & 1.39 \\
\hline 7 & 489 & 37 & 22 & 0 & 548 & 0.971 & 0.917 & -0.055 & 0.01 & 0.595 & 2.91 \\
\hline 8 & 407 & 53 & 45 & 8 & 513 & 0.912 & 0.851 & -0.060 & 0.03 & 0.849 & 1.68 \\
\hline 9 & 314 & 61 & 42 & 20 & 437 & 0.893 & 0.808 & -0.085 & 0.00 & 0.689 & 1.80 \\
\hline 10 & 236 & 28 & 38 & 5 & 307 & 0.927 & 0.886 & -0.042 & 0.12 & 1.357 & 1.57 \\
\hline 11 & 186 & 52 & 44 & 10 & 292 & 0.855 & 0.821 & -0.033 & 0.36 & 0.846 & 1.23 \\
\hline 12 & 61 & 62 & 60 & 42 & 225 & 0.527 & 0.569 & 0.042 & 0.51 & 0.968 & 0.91 \\
\hline
\end{tabular}

Table C2.-Descriptive Statistics of Matched Households: Best Match in Enumeration Area versus Best Match in Sample

\begin{tabular}{|c|c|c|c|c|c|c|}
\hline & \multicolumn{2}{|c|}{$\begin{array}{l}\text { Best Match } \\
\text { in EA }\end{array}$} & \multicolumn{2}{|c|}{$\begin{array}{l}\text { Best Match } \\
\text { in Sample }\end{array}$} & \multicolumn{2}{|c|}{ Difference } \\
\hline & Mean & Standard Error & Mean & Standard Error & Mean & $\operatorname{Pr}>\mid t$ \\
\hline \multicolumn{7}{|c|}{ Household Characteristics } \\
\hline Floor size $\left(\mathrm{m}^{2}\right)$ & 70.969 & 0.597 & 76.070 & 0.798 & -5.101 & 0.000 \\
\hline Wall quality high & 0.840 & 0.004 & 0.811 & 0.005 & 0.029 & 0.000 \\
\hline Roof quality high & 0.464 & 0.006 & 0.458 & 0.006 & 0.007 & 0.424 \\
\hline Floor quality high & 0.590 & 0.006 & 0.595 & 0.006 & -0.005 & 0.558 \\
\hline Electricity & 0.665 & 0.006 & 0.669 & 0.006 & -0.003 & 0.666 \\
\hline Private water source & 0.541 & 0.006 & 0.528 & 0.006 & 0.013 & 0.110 \\
\hline Easy-access water source & 0.490 & 0.006 & 0.513 & 0.006 & -0.024 & 0.005 \\
\hline Toilet & 0.393 & 0.006 & 0.424 & 0.006 & -0.031 & 0.000 \\
\hline \multicolumn{7}{|c|}{ Household Composition } \\
\hline Household size & 5.710 & 0.019 & 5.381 & 0.019 & 0.329 & 0.000 \\
\hline No. of children of household head* & 3.335 & 0.018 & 3.096 & 0.017 & 0.239 & 0.000 \\
\hline No. of daughters of household head* & 1.590 & 0.014 & 1.526 & 0.013 & 0.174 & 0.000 \\
\hline No. of sons of household head* & 1.745 & 0.014 & 1.570 & 0.014 & 0.064 & 0.001 \\
\hline \multicolumn{7}{|c|}{ Household Head and Spouse } \\
\hline Primary head is female & 0.000 & 0.000 & 0.001 & 0.000 & 0.000 & 0.414 \\
\hline Age of female head or spouse (FH) & 40.174 & 0.079 & 42.547 & 0.090 & -2.373 & 0.000 \\
\hline Age of male head or spouse (MH) & 45.746 & 0.093 & 48.887 & 0.106 & -3.142 & 0.000 \\
\hline School years, FH 20-39 & 5.876 & 0.060 & 6.645 & 0.082 & 0.768 & 0.000 \\
\hline School years, FH 40-59 & 5.706 & 0.066 & 5.112 & 0.057 & -0.594 & 0.000 \\
\hline School years, FH $60+$ & 4.050 & 0.723 & 3.887 & 0.472 & -0.163 & 0.850 \\
\hline School years, MH 20-39 & 6.837 & 0.093 & 7.168 & 0.126 & 0.331 & 0.035 \\
\hline School years, MH 40-59 & 7.142 & 0.058 & 7.182 & 0.061 & 0.040 & 0.631 \\
\hline School years, MH $60+$ & 5.264 & 0.180 & 4.426 & 0.118 & -0.838 & 0.000 \\
\hline No. of observations (HHs) & \multicolumn{2}{|c|}{6,968} & \multicolumn{2}{|c|}{6,968} & & \\
\hline
\end{tabular}

* Includes only households where household head has children.

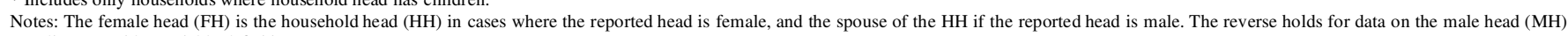
Appendix B provides variable definitions. 
Table C3.-Consumption of Matched Households: Best Match in Enumeration Area versus Best Match in Sample

\begin{tabular}{|c|c|c|c|c|c|c|}
\hline & \multicolumn{2}{|c|}{$\begin{array}{l}\text { Best Match } \\
\text { in EA }\end{array}$} & \multicolumn{2}{|c|}{$\begin{array}{l}\text { Best Match } \\
\text { in Sample }\end{array}$} & \multicolumn{2}{|c|}{ Difference } \\
\hline & Mean & Standard Error & Mean & Standard Error & Mean & $\operatorname{Pr}>|t|$ \\
\hline \multicolumn{7}{|c|}{ Per Capita Consumption } \\
\hline Food & 28,715 & 760 & 30,570 & 1,174 & $-1,855$ & 0.102 \\
\hline Alcohol \& tobacco & 2,769 & 82 & 3,117 & 240 & -349 & 0.152 \\
\hline Alcohol \& tobacco, adult pc & 5,303 & 158 & 5,500 & 298 & -197 & 0.51 \\
\hline Health and ceremonies & 3,548 & 310 & 3,238 & 288 & 310 & 0.326 \\
\hline Other nonfood & 23,468 & 1,506 & 26,049 & 2,006 & $-2,580$ & 0.169 \\
\hline All nonfood & 29,785 & 1,609 & 32,404 & 2,154 & $-2,619$ & 0.196 \\
\hline Total & 58,500 & 2,196 & 62,974 & 3,081 & $-4,474$ & 0.126 \\
\hline \multicolumn{7}{|c|}{ Household Consumption Shares } \\
\hline Food & 0.574 & 0.005 & 0.558 & 0.008 & 0.016 & 0.038 \\
\hline Tobacco and alcohol & 0.059 & 0.002 & 0.059 & 0.002 & 0.000 & 0.962 \\
\hline Health and ceremonies & 0.199 & 0.010 & 0.191 & 0.013 & 0.007 & 0.534 \\
\hline Other nonfood & 0.167 & 0.010 & 0.191 & 0.015 & -0.024 & 0.085 \\
\hline All nonfood & 0.426 & 0.005 & 0.442 & 0.008 & -0.016 & 0.038 \\
\hline Number of observations (HHs) & 6,968 & & 6,968 & & & \\
\hline
\end{tabular}

